Снежана Ненезић

Народна библиотека Крушевац
УДК 371.3:004.738.5

доИ https://doi.org/10.18485/

melissa.2016.15.2.ch13

\title{
РАЗВОЈ ДИГИТАЛНЕ ПИСМЕНОСТИ
}

\section{Сажетак}

Експоненцијални пораст информација, све већа количина информација и разноврсност извора карактеристике су актуелног тренутка. Развој информационих технологија променио је начин на који примамо информације, учимо, свакодневну комуникацију - пословну и приватну. Друштво се све више дигитализује. Карактеристика Интернет културе је паритиципативност, али један део друштва који није овладао употребом информационо-комуникационих технологија остаје маргинализован.

Према истраживањима Републичког завода за статистику у Србији у 2015. години 63,8\% домаћинстава поседује Интернет прикључак, што је повећање од 1\% у односу на 2014. или 8\% у односу на 2013. годину. Преко 2.890.000 лица користи рачунар сваког или готово сваког дана, док је преко 3.550.000 лица користило Интернет у последња три месеца.

Дигитална писменост која данас постаје базично знање подразумева језичку писменост. Језичка култура на интернету је на енглеском језику. Дигитална писменост у контексту употребе интернета као „најдемократскијег средства комуникације“ доприноси образовању грађана, предузетничкој иницијативи, подиже ниво културне свести. Читање текстова на различитим језицима развија мултикултуралност и креативност, укида географске баријере између документа и корисника.

Дигитална писменост постаје једна од кључних вештина у процесу образовања и постаје универзална вештина која се примењује у различитом окружењу.

Форма електронске комуникације је променила комуницирање у приватној сфери, писма замењују мејлови и СМС-поруке, тако и пословну комуникацију.

Кључне речи: дигитална писменост, коришћење Интернета, свакодневно комуницирање

Дигитална писменост која данаспостаје базично знањеподразумева језичку писменост. Језичка култура на интернету је на енглеском језику. Дигитална писменост у контексту употребе интернета као „најдемократскијег средства комуникације“ доприноси образовању грађана, предузетничкој 
иницијативи, подиже ниво културне свести. Читање текстова на различитим језицима развија мултикултуралност и креативност, укида географске баријере између документа и корисника. Дигитална писменост постаје једна од кључних вештина у процесу образовања и постаје универзална вештина која се примењује у различитом окружењу.

Форма електронске комуникације променила је комуницирање у приватној сфери, писма замењују мејлови и СМС-поруке, тако и пословну комуникацију. Према истраживању Републичког завода за статистику, рађеног према моделу Eurostata у Србији: 64,4\% домаћинстава поседује рачунар ${ }^{1}, 63,8 \%$ домаћинстава поседује Интернет прикључак (18,5\% 2006. године) ${ }^{2}, 53,1 \%$ домаћинстава која имају прикључак користе DSL (ADSL) ${ }^{3}$, преко 3.550.000 лица користило је интернет у последња три месеца ${ }^{4}$, преко 2.890.000 људи користи интернет сваког или скоро сваког дана (у односу на 2014. годину број лица повећао сеза скоро 80.000)5, преко 1.500 .000 лица користи неки од е-сервиса јавне управе ${ }^{6}, 97,4 \%$ популације од 16 до 24 године има налог на некој од мрежа Фејсбук, Твитер. ${ }^{7}$ Ови подаци се односе на 2015. годину, док нови подаци за 2016. годину поакзују да скоро $100 \%$ предузећа у Србији користи у свом пословању Интернет. На ово осавремењивање предузећа је утицала пореска администрација и потребе Министарства финансија (обрачун плата запослених, пореске пријаве - раде се онлајн одређеног дана у месецу).

Развој дигиталних вештина је заједно са познавањем језика и предузетничким вештинама у средишту агенде Европске уније за

1 http://pod2.stat.gov.rs/ObjavljenePublikacije/G2015/pdf/G20156007.pdf, 12. (доступпно 22.09.2016.)

2 http://pod2.stat.gov.rs/ObjavljenePublikacije/G2015/pdf/G20156007.pdf 14. (доступпно 22.09.2016.)

3 http://pod2.stat.gov.rs/ObjavljenePublikacije/G2015/pdf/G20156007.pdf 16. (доступпно 22.09.2016.)

4 http://pod2.stat.gov.rs/ObjavljenePublikacije/G2015/pdf/G20156007.pdf (доступпно 22.09.2016.)

5 http://pod2.stat.gov.rs/ObjavljenePublikacije/G2015/pdf/G20156007.pdf (доступпно 22.09.2016.)

6 http://pod2.stat.gov.rs/ObjavljenePublikacije/G2015/pdf/G20156007.pdf (доступпно 22.09.2016.)

7 http://pod2.stat.gov.rs/ObjavljenePublikacije/G2015/pdf/G20156007.pdf (доступпно 22.09.2016.) 
развој вештина. Уместо појма дигитална писменост у новије време уобичајено је користити појам дигитална компетенција. Дигитална компетенција наводи се као једна од осам темељних компетенција за доживотно образовање које је одредила ЕУ да успешно одговори изазовима развоја друштва знања и светског тржишта.

Дигитална компетенција односи се на оспособљеност за сигурну и критичку употребу информационо комуникационих технологија за рад, у приватном и друштвеном животу и комуникацији. Њени су кључни елементи основне информационо-комуникационе вештине и способности: употреба рачунара за проналажење, процену, похрањивање, стварање, приказивање и развијање информација и развијање сарадничких мрежа путем интернета.

Још 1989. године Америчко библиотекарско друштво (American Library Association : ALA) дало је одређење, тј. формулацију да су информационо писмене особе „оне које су научиле како учити - јер знају како је знање организовано, како пронаћи информације и користити се њима. Као прво треба бити свестан потребе за информацијом, препознати информацију која може решити проблем, препознати потребну информацију, затим да вреднују информацију, организују је и користе информације. Такође је препоручено да се реструктурира процес учења.

За разлику од дигиталне писмености, информациона писменост обухвата целокупан универзум информација и оне уштаманом облику и зато је шири појам од дигиталне писмености, јер све информације још нису у електронском облику.

Дигитална писменост у Србији реализује се у оквиру програма „Друга шанса“ - Развој система функционалног основног образовања одраслих у Србији.

Дигиталнаписменостилиипотребаинформационо-комуникацијских технологија у оваквим програмима се обично наводи као један од општих исхода. Дигитална писменост посматра се и као базично знање јер, поред осталог, омогућава и приступ највећем извору података и знања, и баратање тим подацима, а самим тим значајно олакшава стицање свих других вештина и исхода образовних програма. Уз то, искуства програма функционалног образовања одраслих показују да употреба рачунара снажно поспешује мотивацију одраслих за учешће у оваквим образовним програмима, што је додатни подстицај постизању свих општих исхода. 
Експоненцијални развој знања и драматично растућа количина и доступност информација, као и разноврсност извора информација су доминантне карактеристике света у коме живимо. Превасходни „кривац“ за такво стање је лакоћа са којом продукујемо, трансформишемо и манипулишемо дигиталном електронском информацијом. Информационо-комуникацијске технологије базиране на тој дигиталној информацији су у последњој деценији створиле нов поглед на свет, и драстично промениле начин на који сазнајемо, учимо, комуницирамо, организујемо и реализујемо посао, организујемо своје приватне обавезе и проводимо слободно време.

Све говори уприлогтоме да ће се друштвени развој и даље кретати у правцу све веће дигитализације друштва - у погледу организације и функционисања тржишта роба и услуга, јавног сектора, у погледу продукције и дистрибуције сервисних и других информација, у погледу организације и реализације друштвених односа... Чињеница да се друштво све више дигитализује истовремено значи да један део популације у друштву све мање партиципира.

Процес дигитализације друштва је истовремено процес маргинализације оног дела популације који овом свету дигиталних инфомација и услуга не зна да приступи. Ово раслојавање додатно убрзавају могућности које информационо-комуникацијске мреже пружају реализацији концепта доживотног учења. Практично они који имају приступа овом дигиталном свету у прилици су да своју свеколику егзистенцију осетно унапреде, а они који немају могу сутра изгубити и оно што су до јуче веровали да им је неотуђиво.

Све ово чини да дигитална писменост буде препозната као базична животна вештина, круцијална да се у нагло измењеном свету успешно реализујемо у својим животним улогама. ${ }^{8}$

Подаци који говоре у прилог овоме показују да је 1995. године било 35 милиона корисника интернета или 0,6\% популације, док је овај број 2014. године достигао 2,8 милијарди корисника интернета или $39 \%$ популације. ${ }^{9}$

8 ДИГИТАЛНА ПИСМЕНОСТ http://digitalnapismenost.oshrs.edu.rs/ (доступпно 22.09.2016.)

9 http://iab.rs/wp-content/uploads/2015/06/Internet Trends 2015.pdf (доступпно 22.09.2016.) 
Виртуелна култура данас значи радити и играти се на Интернету. ${ }^{10}$ Први научни чланак где се користи термин «дигитална социологија» у називу појавио се 2009. године. Аутор одражава начине на које дигиталне технологије могу да утичу како на социолошка истраживања тако и на учење. У 2010. години, појам «дигитални социологија“ описао је Ричард Нил.

Виртуелна култура среће се и под синонимима сајбер култура, дигитална култура, интернет култура, култура мреже, итд. - сви ови термини указују на неку од доминантних карактеристика окружења у којем се одвијају комуникација и размена информацијам пре свега на улогу у генерисању појединца и његовог/њеног времена и простора. Култура мреже је „једна врста Есперанто културе, то је „ван-времена“ и „ван-просторна култура“ - у сопственим терминима она постоји само у „реалном времену“, култура је без правца у (територијалном) прстору или свеза у (историјском) времену. Овај феномен објашњава и формулише Ива Ненић у делу „Култура сајбер простора“.

Зборник есеја „Виртуелна култура“ (књига је први пут објавена 1997. у преводу на српски 2001. године) аутора Стивена Џоунса указује на питање комуникације и сајбер окружења. Џоунс је поставио смернице за проучавање интернета као простора који се не тумачи као „футуристички кибер.ж простор“ већ као дисконтинуирани наративни простор. Полазећи од ове тезе, Џоунс интернет не сагледава као утопију која ће решити или надоместити постојеће друштвене утопије, већ га разматра превасходно као могућност реализовања различитих облика виртуелног заједништва. Уводи и појам сајбер времена, у покушају да укаже на још један од важних топоса постомодерног доба - празнину времена, условљену тиме што „слабије осећамо његово протицање, а јаче његов дисконтинуитет. Џоунс имплицира да стварност интернета и озбиљни утицаји које та заједница врши на свакодневницу захтева критичко промишљање међуутицаја онлајн и офлајн комуникације.

Интернетсе може одредити као значењски фронтално окружење у чије се кодове „пресликавају“ свакодневни чинови субјеката или

10 https://web.cs.dal.ca/ eem/cvWeb/pubs/Tastsoglou NetworkNetplay.pdf 22.09.2016.) 
друштвене групе, окружење које је новина само по себи (у смислу самог медија), али и у погледу начина на који реконструише процес комуникације,

Повећан утицај компјутера и дигиталних садржаја утицао је како на кориснике библиотека, тако и на библиотекаре. Развој технологије развио је очекивање за информацијом y full text-у. Употреба технологија у библиотекама је еволуирала библиотечке послове, организациону структуру, промењени су услови рада, организација простора.

Како су библиотеке део друштва и рефлектују промене у друштву - концепт виртуелне библиотеке одговор је променама на интелектуалном, друштвеном и психолошком плану деце и одраслих. Током 90-тих термин виртуелна библиотека постао је стандардан начин описивања библиотека које нуде приступ дигиталним информацијама.

Интернет је примарна инфраструктура за виртуелне библиотеке. Утицај савремених технологија у крирању виртуелних библиотека произвео је промену радног окружења. Одговор библиотека је у развијању нових услуга. Носталгије за библиотекама какве су биле у прошлости и страх од развоја технологија у будућности не сеже револуционарне промене.

Током 90-тих година у САД је развијена концепција Библиотека треће место - омогућава физички простор за друштвени контакт и друштвено искуство ван куће / посла. Институције као фитнес центри, библиотеке, салони лепоте су примери трећег места - простор где се људи окупљају у размењују искуство и ствари које су важне за њих. Како библиотеке имају дугу традицију повезивања и друштвена заједница их поставља у традиционално треће место. Исто тако су креиране веб странице и развијају се у смислу трећег места чији се значај увећава у стварном животу и у сајбер простору.

Веб је променио наше навике, очекивања и норме. На интернет се гледа као на информациони универзум, очекујемо да информације буду доступне - у тексту и другим форматима - информације. Информације нису креиране само од стручњака већ и од аматера. Више него икад пре може да се бира шта, када и како користити информације. 
Веб и начин комуницирања, интеракције са њим постао је део наше културе. Као резултат су промене узроковане природом информација које су се и саме промениле.

Информациона писменост подразумева три основне вештине: основно познавање информационих технологија, вештине за препознавање информационих ресурса као и способност да се идентификују корисни ресурси и вештина критичког мишљења.

Навике корисника директно утичу на даљи равој информационо - комуникационих услуга, изглед веб странице и позиционирање садржаја, као и комерцијализацију простора рекламним услугама.

Нет генерација се осећа удобно и безбедно у онлајн окружењу. Док четују, Facebook, Flicker, са пријатељима пријатеља са којима имају сличан интерес преко друштвених мрежа, док се у стварности никада нису срели. Веза постоји онлајн, обогаћена је разменом профила, текстова, фотографија, музике...

Препорука OCLC -а је да библиотечки ресурси морају повећати видљивост у умреженим информацијама али и да библиотеке више немају монопол на пружању информација. Данас студенти и корисници библиотека не траже помоћ библиотекара за коришћење информационих ресурса библиотеке, било да су у питању физички или виртуелни извори.

Виртуелне платформе библиотека засноване су на активностима комплементарним традиционалним методама. Активности засноване на физички дигиталном простору одражавају идентични будући физички простор.

Googl Books - помажу корисницима да открију нове, али и старе књиге као и да листају и читају странице књига.

Данашњи корисници имају виши ниво информационе писмености. Али нису се променили само корисници, променио се и начин креирања, употребе и дисеминације информација.

Информационе технологије су постале део културе. Web 2.0 омогућава нове опције за конекцију и комуникацију потпомогнут друштвеним мрежама помаже људима да пронађу једни друге, шире информације измеђупријатеља и пријатеља пријатеља. Комуникација од једног ка другом постаје једни према другима. 
Култура на интернету је партиципативна - алати лако повезују кориснике, који нису само ограничени на примање информација, већ коментаришу, сарађују и креирају своје садржаје. Илустрација су примери шеровања садржаја, лајковања или хејтовања.

Библиотеке су се врло брзо приклониле новим тенденцијама и почеле да користе друштвене мреже за популаризацију својих услуга, најаву дешавања. Овако створене групе за подршку омогућавају библиотекама да поделе садржаје и догађаје, да утичу како на физичке, тако и на виртуелне кориснике, од којих имају или немају подршку за рад. Не треба посебно помињати да поједини, који су редовни посетиоци веб сајта библиотеке, Фејса, лајкују и хејтују физички не посећују библиотеку.

\title{
Snežana Nenezić
}

\section{DEVELOPMENT OF DIGITAL LITERACY}

\begin{abstract}
Summary
Exponential increase of information, all of a larger quantity and variety of information sources are the characteristics of the current moment. The development of information technology has changed the way we receive information, we learn everyday communication - business and personal. Society is increasingly digitized. The characteristic of Internet culture is pariticipations but one part of society that has not oportunity the use of information and communication technologies and they remains marginalized. According to research in Serbia during 2015, 63.8\% of households have Internet access, an increase of $1 \%$ compared to 2014 , or $8 \%$ compared to the 20,123 th year. Over 2,890,000 persons use a computer every day or almost every day, while more than $3,550,000$ persons used the Internet in the last three months. Digital Literacy, which has become a basic knowledge. Language culture on the Internet is in English. Digital literacy in the context of using the Internet as "the most democratic means of communication" contributes to education of citizens.

Reading texts in different languages develop multiculturalism and creativity, repealing geographical barriers between the documents and users. Digital literacy is be-
\end{abstract}


coming one of the key skills in the education process and becomes a universal skill that is applied in different settings. Form Electronic Communications has changed communication in the private sphere, the letters are replaced by e-mails and SMS messages, as well as business communication.

Key words: digital literacy and Internet use, daily communication 